\title{
Understanding the Context of Community-Based Learning in Kenya: Sociocultural, Diversity, and Linguistic Issues
}

\section{Charlene A. VanLeeuwen}

University of Prince Edward Island, Canada

Linyuan Guo-Brennan

University of Prince Edward Island, Canada

Lori E. Weeks

Dalhousie University, Canada

\section{Recommended Citation:}




\title{
Understanding the Context of Community-Based Learning in Kenya: Sociocultural, Diversity, and Linguistic Issues
}

\author{
Charlene A. VanLeeuwen \\ Linyuan Guo-Brennan \\ University of Prince Edward Island, Canada \\ Lori E. Weeks \\ Dalhousie University, Canada
}

\begin{abstract}
Many African higher education institutions have adopted community-based learning (CBL) to foster highquality learning and civic engagement. In Kenya, neocolonial practices of using Eurocentric community service-learning models have caused tensions and disconnection between CBL theory and university students' experiences in the field. Using hermeneutics as its theoretical and methodological framework, an interpretive study analyzed Kenyan university students' experiences and perspectives on CBL in diverse community and organizational settings. This article reports the study's findings related to students' encounters with unique sociocultural, diversity, and linguistic issues connected to CBL in Kenya, including encounters with the intense realities of HIV/AIDS. Findings and discussion of these issues contribute to a deepened understanding of civic engagement programs in Kenya and offer new perspectives on developing culturally relevant CBL programs.
\end{abstract}

Keywords: African higher education, community-based learning, hermeneutics, interpretive study, Kenya

\section{El contexto del aprendizaje basado en la comunidad en Kenia: Aspectos socioculturales, lingǘsticos y de diversidad}

Muchas instituciones africanas de educación superior han adoptado el aprendizaje basado en la comunidad (ABC) como método para promover el aprendizaje de alta calidad y el compromiso cívico. En Kenia, las prácticas neocoloniales que emplean modelos de aprendizaje a través del servicio a la comunidad han causado tensiones y desconexión entre la teoría y las experiencias de campo de los estudiantes universitarios. Usando la hermenéutica como marco teórico y metodológico, un estudio interpretativo ha analizadolas experiencias y perspectivas de los estudiantes universitarios kenianos acerca del ABC en diversos escenarios comunitarios y organizacionales. Este artículo presenta los resultados de dicho estudio en relación con las experiencias de los estudiantes kenianos en aspectos lingüísticos, socioculturales y de diversidad conectadas al $\mathrm{ABC}$, incluidas sus vivencias con la dura realidad del HIV/SIDA. Las conclusiones acerca de estos aspectos contribuyen a profundizar en la comprensión de los programas de compromiso cívico en Kenia y ofrecen nuevas perspectivas para el desarrollo de programas de $\mathrm{ABC}$ culturalmente relevantes.

Palabras clave: educación superior en África, aprendizaje basado en la comunidad, hermenéutica, estudio interpretativo, Kenia.

Editors' Note: Translation by Beatriz Calvo-Peña Department of English and Foreign Languages Barry University, USA 
Higher education has embraced community-based learning (CBL) as an engaging pedagogy that offers students opportunities to experience issues they are studying in real-world settings that promote social responsibility. Ideally, students in CBL placements are supported and guided by field supervisors and instructors as they consolidate and apply their foundational knowledge and skills in new or less familiar community contexts. Previous research has shown that CBL placements in settings where extreme inequality exists can actually perpetuate inequity and reinforce systems of privilege (McMillan \& Stanton, 2014; Mitchell, 2008; Mitchell et al., 2012). This article discusses findings from a hermeneutic study that examined university students' CBL experiences in Kenyan communities and describes how students' experiences were influenced by the historical and sociocultural context of Kenya - a country with a long colonial history that continues to grapple with critical issues of inequity (Adoyo \& Odeny, 2015; Greiner \& Sakdapolrak, 2013; Karanja, 2010; Meda, 2013). As Kenyan perspectives of CBL are largely missing from the exiting literature, this hermeneutic inquiry provides new insights and understandings of CBL in Kenya by highlighting how undergraduate university students made meaning of their experiences and how contextual factors affected those experiences.

\section{An Overview of Community-Based Learning in Higher Education}

In focusing on CBL placements in Kenya - as opposed to transnational CBL, which is frequently used by study abroad programs - this study relied on Bringle and Clayton's (2012) widely accepted definition of community service-learning; however, we use the term community-based learning in recognition of concerns that the word service may raise among those who have experienced oppression (Jacoby, 2014).

Existing literature, primarily from Western higher education settings, has clearly established CBL as a philosophy, educational model, and pedagogy that can produce positive outcomes for all stakeholders within higher education institutions by strengthening a university's relationship with its surrounding communities (Cloete et al., 2011; Finley, 2014; Fitzgerald, 2007; Mitchell, 2008; Pollack, 2014; Xing \& Ma, 2010). As a pedagogy, CBL activities and reflections support students through academic learning, through the development of deeper and more critical understandings of community and social responsibility, and by bridging the theory-practice gap (Mitchell et al., 2012). Community-based learning allows students to make connections among their prior learning, their social, cultural, and historical context, and the community setting. It can also enhance the complexity of students' thinking, feeling, relating, and acting (Chambers, 2009; Clayton et al., 2013a; Giles \& Eyler, 1994a; Lee \& Chen, 2014; Simons et al., 2012; Swaner, 2012; Xing \& Ma, 2010); develop their relationship-building skills as they work closely with field supervisors, partnering institutions, and university instructors (Kathuri-Ogola et al., 2015; Preece, 2016; Sharpe \& Dear, 2013); and transform perspectives of students, faculty, staff, and communities (Brownell \& Swaner, 2010; Finley, 2014). Such positive outcomes can only be achieved through a deep understanding of the contextual factors affecting CBL stakeholders, including students, faculty, and community partner organizations (Clayton et al., 2013b; Hartman et al., 2018; Mitchell, 2008). In addition, incorporating Indigenous perspectives into CBL theory and praxis is critical in developing CBL models, pedagogical approaches, and practices that are responsive to the sociocultural characteristics and needs of local communities (Bocci, 2015; VanLeeuwen et al., 2017).

\section{The Need for CBL Research in Kenya}

The UN's Sustainable Development Goals (United Nations, 2015) have identified postsecondary education as an important strategy and venue for eradicating poverty, making education available for all, and achieving gender equity in African countries, including Kenya. Many higher education institutions in Africa have adopted CBL to foster high-quality learning and civic engagement, and to ensure that students' education contributes to not only their earning ability, but also their capacity to make positive contributions to society (Ondigi, 2011; Opiyo-Newa, 2012; Tumuti et al., 2013; Weisbrod et al., 2011). As a result, undergraduate students are required to engage in CBL through practicums or "attachments" as graduation requirements, or are encouraged to pursue CBL experiences through co-curricular activities 
(Tumuti et al., 2013). Scholars have long called for more systematic generation of knowledge using greater theoretical and methodological rigor (Bringle, 2003; Giles \& Eyler, 1994b, 2013; Eyler, 2002, 2009; Whitley, 2014), and studies have warned that importing Western pedagogies and practices into African contexts can be problematic (Crabtree, 2008; Fourie, 2003; O'Brien, 2005). However, the extent to which African perspectives, traditions, and needs have been incorporated into existing CBL theory and praxis in African higher education remains under-examined since much of the CBL research has been conducted in settings outside of Africa.

Research into CBL in Africa is challenged by the limited utilization of local epistemologies, a shortcoming exacerbated by a small number of studies (Fourie, 2003; O'Brien, 2005), in this case from Kenya (Mukuria, 2008; Odongo, 2018; Ondigi, 2011; Tumuti et al., 2013). Comparative studies examining Western and Africanized models of CBL have questioned the effectiveness of neocolonial practices that use Eurocentric CBL models to help African students relate to their real-world learning experiences (Hatcher \& Erasmus, 2008; Le Grange, 2007; Stanton \& Erasmus, 2013). Understanding the community learning contexts and the relationships among students, institutions, and the community is critical for enabling each stakeholder in a CSL partnership to optimize their capital, resources, and ongoing growth (van Wyk \& Daniels, 2004). However, in Africa, such understanding is not readily available to maximize students' CBL learning outcomes (Odongo, 2018).

The educational system in Kenya has long been preoccupied with testing and training for white-collar employment, and has focused on globalisation at the expense of local needs. Consequently, youth and university students are often isolated from the lived realities of their communities as they focus on their studies, typically in boarding schools away from their home communities (Tumuti et al., 2013). This disconnection has led to distress when students encounter social issues. Though community engagement programs in higher education have been reported as effective strategies for countering such distress (Tumuti et al., 2013), difficult community situations complicated by issues related to language, culture, diversity, HIV/AIDS, and extreme poverty continue to present significant barriers for students and higher education institutions to articulate CBL goals and outcomes (Kabaria-Muriithi et al., 2018; Kathuri-Ogola et al., 2015; VanLeeuwen et al., 2018). In addition, efforts to understand CBL in Kenya are complicated by several unique contextual factors. First, the significant increase in the number of public and private institutions and in student enrollment have led to a phenomenal expansion of Kenyan university programs, serious overcrowding, and inadequate infrastructure (Gudo et al., 2011; ICEF Monitor, 2015; Nyangau, 2014; Oanda \& Jowi, 2012). Second, the neocolonial practice of using Eurocentric CSL models at Kenyan universities has caused tensions and disconnection between CBL theory and students' experiences in the field (Le Grange, 2007; Stanton \& Erasmus, 2013; VanLeeuwen et al., 2017). Third, the AIDS epidemic in Kenya has exacerbated extreme poverty, severe stigma, and inequity (Kohler et al., 2014; Mudavanhu, 2008; Mudavanhu et al., 2008). Fourth, inequities related to gender, language, and ethnic groups, as well as asymmetric power relationships, require tactful professional wisdom from community service professionals (Adoyo \& Odeny, 2015; Greiner \& Sakdapolrak, 2013; Karanja, 2010; Meda, 2013). However, these distinctive contextual issues relevant to CBL in Kenya differ from the primary issues discussed in the current CBL literature, which reflects theoretical and contextual perspectives gained predominately from Western contexts (Mitchell, 2008; VanLeeuwen et al., 2017).

Deeper inquiry using critical lenses that explicate historical, cultural, racial, and political issues can help researchers and university educators acknowledge, understand, and honour differences (Boler \& Zembylas, 2003; Dei, 2000; McMillan \& Stanton, 2014; Mitchell, 2008; Roos et al., 2005; Thomson et al., 2011; Tonkin, 2011; Zembylas, 2015). More specifically, understanding the distinctive contextual settings and experiences of Kenyan students - and what diversity in CBL means to them - is essential for developing curricular initiatives built on effective practice and sound evidence.

\section{Research Purpose and Theoretical Framework}


The purpose of this interpretive inquiry was to understand how Kenyan university students made meaning of their CBL experiences and how these experiences were influenced by the historical and sociocultural context of Kenya. A deepened understanding of Kenyan university students' CBL experiences is critical for decolonizing existing CBL theory and praxis, and contributes to developing culturally responsive CBL curricula and programs in international settings.

We adopted hermeneutics, the theory and methodology of interpretation, as the framework for this study because it encourages critical engagement with historical context, cultural tradition, and prior knowledge in an effort to understand and interpret experiences (Davey, 2006; Gadamer, 1960/1975; Guo, 2010; McCaffrey et al., 2012; Moules, 2002; VanLeeuwen et al., 2017). Within this theoretical and methodological framework, prejudices and traditions are viewed as positive requirements for making a claim of knowledge and understanding. This awareness sensitizes interpreters to cultural and academic filters that may be employed or encountered during interpretation (Gadamer, 1960/1975). Understanding and interpretation are inseparable in hermeneutic data collection and interpretation because what is learned from another person must first be interpreted with the researcher's own pre-understandings, discussed, and then added to a new horizon (Hovey et al., 2017).

Adopting hermeneutics as a methodological framework meant that the data collection began with an immersion in the literature related to the topic and in the research context (McCaffrey et al., 2012). The understanding of students' CBL experiences only occurred through the fusion of horizons (Gadamer, $1960 / 1975$ ) as both the researchers' and the participants' prior knowledge about the topic was broadened through the new information acquired during research conversations (Binding \& Tapp, 2008). Consideration of what the participants and researchers bring into the hermeneutic circle of understanding is important, especially when the researchers are cultural outsiders and do not share the same sociocultural, linguistic, and educational backgrounds with the participants (VanLeeuwen et al., 2017). Through this dynamic interpretive process, hermeneutics strives to be holistic and integrative as it seeks to understand the topic as a whole in light of its parts.

\section{Methods}

\section{The Research Team}

This research was part of the doctoral work conducted by the first author, a White Canadian woman. The second and third authors were co-supervisors providing guidance and direction. As such, they did not participate in the data collection; rather, they supported the data analysis and writing, along with a trusted Kenyan colleague, a faculty member in the university program in this study who served as a critical friend to the research (Appleton, 2011; Costa \& Kallick, 1993).

The first author's pivotal CBL experiences coalesced with previous research projects conducted with Kenyan colleagues and a longstanding interest in international development. The contextual awareness gained from these prior international research and development experiences, as well as her research position as a scholar outside of the Kenyan cultural, linguistic, and educational context, provided unique opportunities to (a) attend to the sociocultural issues and dynamics associated with power and languages, (b) recognize the colonial traces in CBL praxis in Kenya, and (c) expand the horizons of CBL through the research process (VanLeeuwen et al., 2017).

\section{Research Setting and Participants}

This study took place at a large public university in Kenya where students in over 20 departments are required to complete CBL placements, or attachments, as part of their undergraduate degree requirements. The human service program upon which this study focused prepares graduates to pursue careers with social service organizations (e.g., the civil service, international aid agencies, or nongovernmental organizations [NGOs]) that support vulnerable children, youth, and families, and their communities. Students in this program are placed in a wide range of community and organizational contexts to provide 
social and human services; therefore, they are ideal participants for understanding the complexity of contextual issues related to CBL in Kenya.

In order to identify university students who could contribute diverse and unique stories and experiences related to CBL, all invited participants were screened using a short demographic survey. Following screening, six students were purposefully selected based on their gender, age, ethnicity, and the type of organization in which they were placed for their CBL experience (Moules, 2002; Patton, 2015; Sandelowski, 1995). Three female and three male students ranging in age from 21 to 30 years old were invited to participate in the study. Gathering data from six individuals is usually sufficient for qualitative research studies of this nature, with three in-depth conversational interviews conducted with each participant (Baglin \& Rugg, 2010; Moules, 2002; Sandelowski, 1995). The participants came from four different ethnic groups (i.e., Gikuyu, Luhya, Kalenjin, or Iteso) and had educational and living experiences in either rural or urban settings. All participants had completed their secondary studies at boarding schools before starting university and were fluent in Kenya's two national languages, Kiswahili and English, as well as the language of their ethnic group. At the time of this study, they were in the fourth year of their undergraduate program and had recently completed a 12-week CBL placement with a community organization such as a government department, NGO, faith-based charity, or communitybased organization $(\mathrm{CBO})$.

\section{Data Collection}

Data were collected through open-ended conversations, a focus group, and sharing of artifacts (e.g., photos, work projects). The first author conducted three interviews with each participant over a period of four weeks, with each conversation lasting approximately 45-70 minutes. These conversations were conducted on the Kenyan university campus at times that were convenient for the participants. Openended questions were used to guide conversations about students' learning experiences in communities, knowledge and skills gained, challenges and barriers, and perceptions and experiences with traditional Kenyan ways of knowing during their CBL placements (Binding \& Tapp, 2008; Carson, 1986). Additional questions were generated following each conversation to clarify participants' unfolding stories. When appropriate, techniques such as rewording, clarification, funneling, probing, encouraging storytelling, and summarizing were used to achieve greater depth in the data and to generate openness and curiosity about the topic (Moules et al., 2015; Paterson \& Higgs, 2005). Participants were also encouraged to share artifacts in order to deepen their reflections on meaningful CBL experiences. Each research conversation was digitally recorded and transcribed using Microsoft Word and speech recognition software (i.e., Dragon NaturallySpeaking) and then uploaded to the qualitative data analysis software NVivo.

\section{Data Analysis and Interpretation}

Interpretative analysis encompassed the speaking, listening, sharing, questioning, and reflecting of the participants and researcher in conversation about the students' CBL experiences. This iterative process began prior to the interviews through immersive reading and reflection on literature related to global $\mathrm{CBL}$, the historical and sociocultural context of Kenya, colonialism and decolonization of research, and hermeneutics as philosophy, methodology, and research practice. Data analysis began as soon as the research interviews commenced. The researcher took detailed notes during each research conversation and developed brief summaries that were shared with participants after each meeting. The researcher also listened to recordings of conversations multiple times. In conjunction with field notes and the researcher's journal entries, transcripts were read and re-read. Analysis methods also included reading transcripts aloud, reading other relevant literature to inform emerging interpretations, writing memos and notes, talking to colleagues, paying attention to what was not said, and journaling. In addition, a "critical friend"- a trusted person who asks provocative questions, clarifies ideas, and offers critiques of a person's work - helped clarify contextual understanding and language (Appleton, 2011; Costa \& Kallick, 
1993). Though member checking is often employed in many qualitative methodologies, it is not used within hermeneutic practice and was therefore not utilized in this study (Moules et al., 2015).

Initial analysis of transcripts involved the identification of themes, which served as a starting point for interpretation. These themes were derived through open coding, which permitted openness to unique facets of the topic arising from the raw data. Open coding was also used because of the lack of extant research focusing specifically on CBL in Kenyan settings. The systematic process of moving within the hermeneutic circle by listening to and reading each participant's CBL experiences helped establish an understanding of the topic as a whole and in parts, and to identify key themes from the data (McCaffrey et al., 2012; Moules et al., 2015). After a few rounds of independent reading and reflection, the first author met with other members of the research team to discuss and clarify naïve interpretations before returning to the data. Throughout the analysis, interpretation, and writing process, the research team looked for and compared similarities and dissonances in all transcribed conversations. In addition, the team attended to what was absent in conversations with participants (e.g., conversations about diversity did not include references to LGBTQ2+ issues, intellectual challenges, or mental health concerns). The data analysis and interpretation process for this study was guided by the work of Moules et al. (2015), who conducted hermeneutic research in a number of practice-based disciplines, including education. Data analysis and interpretation continued in this divergent fashion in order to establish "associations which strengthen[ed] understanding of the topic, rather than focusing on a single governing theme" (Moules et al., 2015, p. 117). Interpretation involved listening to and reading what participants said (or did not say) and writing interpretive conjectures, all of which enhanced understanding of CBL in Kenya. Generally, the credibility of interpretations arises from the ways those interpretations bring understanding to the topic (Sandelowski, 1994, as cited in Moules et al., 2015, p. 136), and hermeneutics allows for pluralities in interpretation (Kvale \& Brinkmann, 2009, as cited in Moules et al., 2015, p. 135).

\section{Findings}

The ongoing interpretive analysis of the conversations with each participant revealed a number of themes. Findings presented in this article focus on themes related to diversity issues around CBL in the Kenyan context, one of the core research areas addressed in this study. The key diversity issues affecting student participants' CBL experiences in Kenya included understanding the impact of HIV/AIDS, realizing the important role Indigenous languages play in community services and engagement, valuing the common humanity of different ethnic and religious groups, increasing awareness of social and economic inequities and disparities in Kenya, and understanding discrimination and exclusion in communities and society. Pseudonyms were assigned to participants, and identifying information in quotations was redacted to ensure participants' anonymity.

\section{Participants and Their Community-Based Learning Settings}

All participants in this study had completed a mandatory 12-week CBL placement with a human service organization in Kenya as part of their undergraduate program. Their experiences in various organizational and community settings offered a unique and more holistic understanding of the diversity issues related to CBL in the Kenyan context.

Joy. Joy was 24 years old and grew up in an urban setting within a Gikuyu ethnic community. At the time of the study, she had completed her CBL placement with an organic agriculture training centre. The mission of this organization was to develop a sense of empowerment and self-reliance in communities in order to improve food security and the livelihoods of smallholder farmers while building a healthier environment. The centre offered a range of programming for community members, such as training in organic farming practices, using energy-conserving cook stoves and biogas systems, small livestock husbandry, and income-generating activities for individuals affected by HIV/AIDS. These programs and activities took place at the centre's demonstration plots or in the community. Joy was responsible for managing a pilot program that provided agricultural and financial support to impoverished grandmothers in the local community who were raising their grandchildren. She and her colleagues also carried out 
extension activities with women's groups, including training community members in how to use grow bags for micro-gardens and table banking; learning how to deliver the centre's organic farming training; and mentoring youth participating in the income-generating programs, such as tailoring, basket making, and pottery.

Symo. Symo, 30, came from the Gikuyu ethnic group and grew up in a village in a rural community. Symo's postsecondary studies were delayed after high school due to the combination of his mother's illness and family finances. Like Joy, he was partnered with the organic agriculture training centre, where his role focused on the empowerment of women through training at the centre and in communities in the peri-urban, or rural-urban transition zone, and surrounding rural areas. His responsibilities involved extension activities with local residents, primarily with women's groups and youth who were training at the centre. Extension programs are informal, flexible outreach activities designed to educate entire communities or groups. His social media and graphic-design skills became well-utilized when he was asked to take on responsibilities in this area for the centre. He also created a publication documenting and celebrating the activities of the 10 interns hosted at the centre.

Kiongozi. Kiongozi, 23, was a member of the Kalenjin tribe and grew up in a rural village community. After he graduated from secondary school, his parents could not afford to send him to university, so he postponed his studies for nine months. His CBL placement was with a local children's charitable organization that cared for over 70 children. Since the centre had been ordered to close, Kiongozi spent the first few weeks of his CBL placement working to locate parents and caregivers of the children, conducting sensitization sessions, and liaising with local boarding schools as children moved to new facilities. He also engaged in fundraising for the centre, which had committed to paying school fees for the term. Toward the end of his placement, he converted one of the centre's rooms into a library as the organization shifted to providing recreational and leisure activities for former residents.

Lolo. Lolo, 21, was from the Luhya tribe and grew up in Nairobi. She chose the human service program because she wanted a program that would enable her to address people's needs, especially those related to poverty. Her CBL placement organization was a faith-based charity serving 200 families from the nearby slums. Lolo's primary responsibility was conducting home visits to assess and monitor family needs and eligibility for services as well as children's progress in school. Services provided by the charity included subsidies for school fees or rent and financial assistance with purchasing items such as school uniforms. In addition, the organization operated a Saturday program that served as a means of evangelization and provided meals and some recreational activities (e.g., a singing group or sports) for the children and youth who were sponsored by the agency. Lolo volunteered with the Saturday recreation program in addition to her weekday CBL placement responsibilities.

Ooih. Qoih, 21, was from the Gikuyu ethnic group and grew up in a rural area in central Kenya. During her second year at university, she realized she was much more interested in working with marginalized communities and transferred into this program. Qoih was partnered with the local office of a women's empowerment organization close to her home town. The organization had a high-profile patron and was closely connected with the work of the Women's Representatives, a group of elected government representatives. During her CBL placement, Qoih usually accompanied different program officers when they went out into the community to facilitate outreach sessions on topics such as table banking and poultry husbandry. The program officers would also reach out to women from the community who had moved to Nairobi in order to help them maintain connections with the community. Because of its focus on the empowerment of women, some men in the community initially expressed resistance and bitterness toward the organization. As a result, they began to allow interested men to join the women's groups, with the restrictions that only $30 \%$ of total membership could be male and that men were prohibited from taking on leadership positions. Thus, men were able to benefit from the programs but not take over. This diffused tensions and reduced resistance to programming in the community.

Syl. Syl was 23 years old and grew up in an urban community as a member of the Iteso ethnic group. He made the transition to postsecondary studies immediately after high school as a government-sponsored Joint Admissions Board (JAB) student. Syl's host organization was a provincial district sub-county government office charged with ensuring children's rights and addressing issues around custody, access, 
child support, child labour, and abuse. In addition to the six student interns who were partnered with two staff members, this government office also appointed several volunteer community officers, who were trusted individuals in the community with good working relationships with the office of the chief. The community volunteer officers served as liaisons and translators for the staff and students and helped them identify children in the community in need of support. Chiefs play important roles in ensuring the smooth operation of these communities, assisting government offices in dealing with family issues, disputes, negotiations, or resolutions. Syl's primary responsibilities during CBL placement included conducting home visits as part of custody proceedings, gathering information about the physical environment of the homes, attending court to present home-visit observations and recommendations from the Children's Office, and attending mediation sessions for determining the custody of children.

\section{How Kenyan Students Made Meaning of Critical Contextual Issues}

The themes reported in this section were revealed and synthesized through the deconstructive and reconstructive dialogue between participants sharing their CBL experiences and the researcher attending to disciplinary, historical, cultural, and extra-linguistic factors related to the topic of study (Jacobs, 2014; Moules et al., 2015). These are not the only important themes generated from this study; rather, they represent how students' CBL experiences and the specific contextual factors influencing such experiences can be understood hermeneutically.

Understanding the impact of HIV/AIDS by connecting awareness with reality. All participants in this study shared their experiences with issues related to HIV/AIDs during their CBL placement, indicating the brutal impact of this pandemic disease on Kenyan people and communities. They were well aware of the issues associated with HIV/AIDS from their university studies and from massive public health initiatives by the government and international aid organizations; however, most of the participants had their first face-to-face encounter with the intense realities of HIV/AIDS during their CBL placement.

Like other participants, Joy came to a fuller realization of the burden that many Kenyan grandmothers were shouldering by taking on the responsibility of raising grandchildren in the aftermath of AIDS. In her work with these grandparents and affected families, she also observed the substantial stigma, shame, guilt, and stress associated with having HIV/AIDS. Most of the grandmothers and other caregivers with whom Joy worked had little knowledge of anti-retroviral medication or the critical importance of long-term treatment compliance for HIV/AIDS. This stimulated Joy's reflection on how organizations and professionals might support grandmothers who had to assume traditional parenting roles, deal with survivor guilt, and cope with the financial pressure of raising grandchildren.

Through CBL, all participants observed the ways stigma and resilience associated with HIV/AIDs affected individuals and families. Qoih observed that groups of HIV-positive individuals demonstrated great resilience by providing peer-to-peer support and remaining in mainstream community life. She found it encouraging to see people who were living with HIV come together to fight against stigma and isolation. Symo also noted that extended families, particularly grandmothers, did not send vulnerable children whose parents had died from HIV/AIDS to camps for orphans. Instead, they accepted the responsibility of caring for them, despite the stigma and the fact that their own well-being and that of other family members might be jeopardized by an individual who was HIV-positive. This observation, along with a deepened understanding of the impact of HIV/AIDS on families and communities, enabled Symo and Joy to be more appreciative of the outreach programs offered by the organic agriculture centre, which offered impoverished grandmothers and their families residing in the immediate vicinity financial support for school fees and uniforms and assistance caring for children affected by HIV/AIDS.

With 1.5 million Kenyans living with HIV (UNAIDS, 2017), HIV prevention and quality care not only represent an important field of work for community organizations, but also comprise key concerns for social and community-service programs in higher education. Because the study participants had spent their adolescent years in boarding schools, most of them had not, as adults, had recent direct encounters with individuals living with or dying from HIV/AIDS. Community-based learning provided these students with authentic opportunities to observe the extreme difficulties associated with being HIV- 
positive in Kenya and the resilience of affected individuals and families. CBL enabled them to gain a deeper understanding of the stigma of the disease and acquire knowledge and skills to support individuals and communities in authentic, holistic ways as emerging human service professionals.

Indigenous languages are key to effective community services and engagement. Early in our conversations, several participants discussed the role that language played in their CBL experiences. Participants spoke openly and matter-of-factly about their ethnic heritage and tribal languages as daily realities of Kenyan life. Through CBL, they observed that the significant migration from rural to urban areas had created an urgent demand for professionals able to work in human service settings with widely diverse language needs.

Syl, for instance, noted that language was an important issue affecting his CBL experiences. Most people who came to the Children's Office for assistance were from the Kikuyu ethnic group, but he was unable to communicate directly with these individuals since he spoke a different ethnic language. As a staff member of the Children's Office, he found that his inability to interact with younger children was also an issue. Similarly, Symo indicated that he did not understand the "deep Kikuyu" of the grandmothers, who spoke neither of the two national languages (Kiswahili and English). The inability to communicate with individuals speaking the same tribal language was unexpected for Symo. A certain degree of linguistic evolution over time is typical; however, changes that inhibit clear communication within living generations presented additional challenges to Symo's work with elders in the community. These challenges were resolved by gaining assistance from the community volunteer officers, who served as translators. Yet, working with a translator added another layer of complexity to communications with community members since this approach required students to develop a strong capacity to communicate clearly or feel confident clarifying questions and misunderstandings. Linguistic challenges became opportunities for developing professional skills; indeed, clear communication and nuanced understanding are important capacities for human service professionals.

In describing the slum setting where she was based, Lolo commented, "Every language you can find in Kenya was represented here, so there were many language barriers in almost every interaction." Like other organizations where participants were placed for CBL, Lolo's placement organization used the two national languages of Kiswahili and English as working languages. Lolo talked about the importance of using Sheng, a hybrid vernacular of English and Swahili, in her daily work in urban slum communities:

Working with the youth, you have to develop your Sheng language a bit, so you can build this trust, so they engage more with you. Because they [i.e., urban youth] are more comfortable with the slang, they will express themselves better. If you only use English, you are confining them to that imported language.

English has been used in Kenya for over a century and has been reinforced as the primary communication medium in public domains such as education, government, and media. Lolo's use of imported language indicated that English, as a colonial language and legacy, was not perceived as part of her linguistic identity-and this perception was even stronger among the urban youth with whom she worked. Lolo found that using English only was restrictive and inadequate for conducting community services and that local languages were important for establishing trusting and comfortable relationships with community members. Her ability to speak in Sheng allowed Lolo to gain a deeper understanding of the day-to-day experiences of the youth living in the slums. Through CBL, Lolo became more aware of the "in-between" linguistic, cultural, and identity positioning of Kenyan urban youth, coalesced from the colonial legacy and the multilingual and multicultural context in which they live.

Joy also revealed that the use of local ethnic language helped her connect with community members:

Using even a few [ethnic] words, they say, "Oh, so you know that language. Let me tell you now. You may sit down." They trust you as they know you're making an effort to understand them through their language, not just using the common language.

Joy's use of the term common language indicated that, unlike Lolo, English was a significant part of her language identity. Diving deeper into the role of ethnic languages in relationship building, she realized 
that her greeting in the tribal language opened the door to deeper, more meaningful interactions related to accessing HIV/AIDS testing for children.

Seeing the common humanity of different ethnic and religious groups. The religious diversity of Kenyan society consists generally of followers of Christian faiths (i.e., Catholicism, Protestantism, and other forms of Christianity), Islam, and Traditionalism, though the actual diversity of religious beliefs is broader (Wiesmann et al., 2016). Lolo learned the importance of respecting the religious diversity of the people served by her placement organization, a faith-based charity operated through a Christian church. She noted that despite having evangelization as its mandate, the organization provided both secular and religious activities as well as humanitarian support for children of diverse religious backgrounds. This observation challenged her to think critically about the broader motivations of the organization and the flexibility and openness required to meet the far-reaching needs of urban slum communities.

Community-based learning helped some participants recognize their bias toward and assumptions about groups with different religious backgrounds. Symo shared that his values and assumptions about Muslims changed after his interactions with people with an Islamic background. He commented that assumptions held by people in his circle were inaccurate: "They [i.e., Muslims] are not bad people; they are my friends now." Symo's ability to recognize his prejudice toward Muslims allowed him to reduce his discriminatory behaviors and attitudes at work. During his CBL placement, he also tried to extend this insight beyond religious beliefs and values to a broader range of cultural beliefs and practices.

Community-based learning exposed these university students to religious practices different from their own and required them to confront stereotypes they held. As a result, they became more respectful and tolerant of, and open to, differences and were able to see the common humanity of different ethnic groups and individuals. CBL created a space for students to experience diversity, inviting them to engage in critical reflection on how to provide community services that are inclusive and equitable for all members of the community while respecting and embracing diversity and difference.

\section{Developing Increased Awareness of Social and Economic Inequity and Disparity in Kenya}

As the primary means of sustainable economic development, social mobility, and social development, postsecondary education is often associated with higher social and economic status. As individuals with resources and opportunities to attend university, the student participants in this study were perceived by local community members as possessing higher socioeconomic status and authority, which sometimes presented barriers to learning from community engagement. Kiongozi learned that "when you go to the community, you have to neutralize yourself"; that is, he found ways to show respect for the knowledge that community members had developed outside of school without flaunting his higher level of education.

Extreme social and economic inequities and disparities are a reality for many families and communities in Kenya. CBL provided an environment for the student participants to observe the socioeconomic divide that exists in local Kenyan communities and to develop empathy and respect for the knowledge of community members. Before his CBL placement, Symo had some awareness of the complex cultural and socioeconomic issues affecting the community and understood how preconceived notions about people in different classes had kept community members apart. This awareness was both broadened and challenged during his CBL experience. Through his interactions with older community members, he observed their high level of community-mindedness and realized that this sense of community could be instilled in younger generations. He talked at length about baraza, the act of community members coming together to decide on or plan a project. Symo believed that baraza represented community wisdom in the form of breaking down barriers in community services and development because "coming together will give us power to deal with these issues in the community." Through CBL, university students gained first-hand knowledge and awareness of the intersections of these elements of cultural and socioeconomic diversity in Kenya and how such diversity deepened and enriched their academic learning in classrooms.

Understanding discrimination and exclusion in communities and society. Most participants shared their experiences working with individuals with disabilities, and they talked about the 
discrimination these community members experienced. Describing how individuals with physical disabilities contributed to communities and established meaningful livelihoods, Joy said:

I've never seen vocational training given by students with disabilities before. They are very passionate doing that and told me [change in her tone of voice], "You can just come in, I can train you.". . . Disability can't make you unable to sustain yourself. . . . It doesn’t prevent you from achieving your vision.

Joy also talked about the segregation of abled and disabled groups in communities. However, she did not perceive such segregation as a limitation for disadvantaged groups; rather, she viewed it as a means of providing a safer school or sheltered workshop environment.

Qoih had different perspectives on adults with disabilities. She observed that individuals with disabilities had strong negative assumptions about the rest of the community because they felt left out and treated unfairly, complaining that the community programs and services were purposely set up to disadvantage them and that they were taken advantage of by other people. Qoih's comments revealed that she needed more support in developing an understanding of the exclusion and discrimination expressed by individuals living with a disability.

Conversations with Joy and Qoih revealed that they both believed that communities had done much for individuals living with physical disabilities in Kenya. Several factors could have contributed to this perception, including their limited exposure to the immense challenges encountered by individuals with physical disabilities, the difficult lived realities of abled Kenyans who were socioeconomically disadvantaged, and a lack of understanding of and reflection on social justice issues such as poverty, equity, discrimination, and inclusion.

The study participants shared many compelling encounters with HIV/AIDS and poverty, the multilingual nature of many Kenyan communities, religious diversity, social and economic inequity, and exclusion due to disability through their CBL placements, often noting how challenging they found these situations. In the next section, we discuss the complexity of their CBL experiences and consider implications in light of historical, economic, and sociocultural factors in Kenya.

\section{Discussion}

A deconstructive reading of what was said and not said in the research conversations revealed several important issues related to CBL in the Kenyan context. In this discussion and consideration of implications, we focus on three areas: the intersections of diversity and social issues in Kenya, staying abreast of advances in HIV/AIDs in CBL curricula, and the importance of critical reflection on contextual issues as part of ethical CBL praxis. These highlighted issues reflect some of the unique features of CBL in Kenya and draw attention to aspects of curricular design and institutional practices that can potentially enhance university students' CBL experiences and outcomes.

\section{Intersections of Diversity and Social Issues in CBL in Kenya}

There are over 108 distinct ethnic communities in Kenya, and none of these ethnic groups constitutes the majority of the population (Wiesmann et al., 2016). In addition to the official languages of English and Kiswahili, over 40 Indigenous languages are spoken by Kenyan citizens (Karanja, 2010; Muaka, 2011). Kenya's multilingual and multicultural context signifies that diversity is important to CBL in Kenya, and participants' comments and reflections on their CBL experiences clearly confirmed this point.

In societies and communities, diversity is manifested in forms of culture, race, ethnicity, language, class, (dis)ability, age, religion, socioeconomic status, gender, sexuality, origins of nationalities, and ways of being and knowing (Banks, 2016; Clarke \& Drudy, 2006; Solomon \& Singer, 2011). In this study, participants' CBL experiences were highly impacted by several key diversity issues related to language, ethnicity, religion, gender, age/generation, socioeconomic status, tribe, place of residence, and (dis)ability. Participants' frequent emphasis on learning and challenges in these areas indicated their lack of familiarity with diversity issues in CBL and signified the importance of incorporating this topic in CBL 
curricula. As Cress (2018) noted, when students are overwhelmed, they often experience emotional dissonance or entropy. One goal of CBL is to help students develop agency to move from the emotional intensity of the learning experience toward empathy and insight, which they can carry into their future learning and careers.

Educating students about diversity issues through CBL is important because diversity provides opportunities for students to achieve learning outcomes in six areas: tolerance of difference, stereotype confrontation, recognition of universality, interactions across difference, knowledge about the served population, and belief in the value of diversity and inclusion (Holsapple, 2012). Ignorance of diversity issues can reinforce hostile and exclusionary thinking and practices as well as deeply rooted intolerance and inequality that, in turn, are reproduced beyond students' notice (Solomon \& Singer, 2011).

In CBL, languages play important roles in helping students establish trusting relationships with the people they serve. As revealed in this study, participants' local language abilities were decoded as familiarity, initiation, and social closeness. Their experiences indicated that some of their CBL challenges were generated by tensions between Kenya's official language policy, which privileges English in public domains and education, and the reality of Kenyan communities, where Kiswahili, Sheng, and Indigenous and other ethnic languages are commonly used for communications (Muaka, 2011). Linguistically responsive community services are highly desirable and expected in Kenya, and these must be considered when planning and designing community engagement programs so that students receive support for developing the cultural competency they need to thrive in these environments as emerging human service professionals.

It is worth noting the several diversity issues that were not discussed during the research conversations. First, the topic of race was not mentioned, despite the fact that all of the participants were Black and the first author was White and a cultural outsider. Second, while participants shared powerful stories connected to HIV/AIDS, child trafficking, and the sex trade, concerns related to LGBTQ2+ issues, female genital mutilation, and addictions to substances such as miraa, khat, or alcohol did not emerge during research conversations. Participants were likely influenced by the researcher's position as a middle-aged female researcher and university instructor, and consciously selected examples to illustrate their CBL experiences that avoided these contentious issues. In addition, the latter three issues are highly controversial or illegal in Kenyan society, another likely contributor to participants' silence around these topics. Third, none of the participants spoke about intellectual or developmental disabilities, nor did they refer to mental illness as a form of disability. Fourth, regarding matters of migration, participants frequently talked about internal migration due to post-election violence and experiences with people living in internally displaced person (IDP) camps and slums. However, participants did not mention international immigrants and refugees. Fifth, participants never used the term Indigenous; instead, they frequently used the word tribal when talking about local languages and cultures. Tribal can be a sensitive word in some contexts (such as Canada) as it reflects disrespect for ethnic languages and practices, but the term appears to have positive connotations in Kenya. The similarities and differences surrounding diversity issues in national settings like Kenya require sensitivity and consideration within the context of university-level CBL programs.

\section{Staying Abreast of Developments in HIV/AIDS Programing in the Curriculum}

Curricula in human and community service programs must constantly evolve to reflect changing societal realities. In recent years, just over half of new HIV infections in Kenya have been among youth between the ages of 15 and 24 years, with young women almost twice as likely to contract HIV as young men (Avert, 2018). Innovative HIV/AIDS awareness and prevention initiatives in Kenya have demonstrated some success in reducing the rate of new infections; however, sexual violence continues to place young women at higher risk (Kenya National AIDS Control Council, 2014). In Kenya, high-risk populations vulnerable to HIV/AIDS include grandparents raising their orphaned grandchildren, sero-discordant couples (in which one partner is HIV-positive and the other is negative), women encountering sexual violence, and youth who engage in high-risk behaviours that increase their vulnerability to HIV infection 
(Avert, 2018). Curricular adaptations that offer students more in-depth knowledge and skills for working with these key populations can prepare them for the challenging realities of HIV/AIDS as they enter communities to engage in CBL. Ensuring that curricula remain at the cutting edge of developments in HIV prevention should be a priority of university community-engagement programs for students in human service disciplines in Kenya.

\section{Attending to and Reflecting on Contextual Issues as Ethical CBL Praxis in Kenya}

Designing critical reflection activities that generate, deepen, and document CBL is a multistep process (Ash \& Clayton, 2009). There are various oral and written reflection mechanisms that incorporate feedback and can be interwoven to create an overall reflection strategy that acknowledges the characteristics of research-based criteria for well-designed reflection (Bringle \& Hatcher, 1996). Identifying mechanisms that would be effective for CBL in Kenyan settings, where access to technology and other material resources can be a serious constraint, should be a focus of future research.

Community-based learning that does not attend to the underlying historical or cultural contextual issues in Kenya (or other settings where extreme inequality exists) risks perpetuating inequity and reinforcing systems of privilege (Bocci, 2015; McMillan, 2018; McMillan \& Stanton, 2014; Mitchell, 2008). Such practice is unethical and irresponsible, and it defeats the underlying purposes of engaging students in CBL. In addition, understanding the historical and sociocultural realities of CBL from Kenyan or African perspectives is critical for decolonizing Eurocentric CBL theoretical perspectives and praxis for international contexts in ways that will help university students contribute to greater prosperity, justice, and equity through quality community services relevant to their local communities (Crabtree, 2008; Fourie, 2003; Hatcher \& Erasmus, 2008; Le Grange, 2007; O'Brien, 2005; Stanton \& Erasmus, 2013). This process also provides a space for cross-cultural scholarly collaboration and transnational dialogue on CBL theory and praxis that reflect distinctive sociocultural contexts.

Critical reflection that is supported and guided by university instructors or advisors can be accomplished in many ways - for example, through individual reflections in the field, sharing CBL experiences in post-placement seminars, or peer-learning presentations or activities. Providing meaningful opportunities within the CBL curriculum for students to consider all facets of diversity and to engage through reflection with important key concepts from critical pedagogy will not only help them develop effective techniques and strategies for working respectfully with diverse populations in Kenyan communities, but also serve as opportunities to develop positive attitudes and avoid perpetuation of negative stereotypes (Ash \& Clayton, 2009). These practices can lead to greater social equity and justice for marginalized individuals and families. Critical reflection can also encourage students to give thoughtful consideration to traditional or Indigenous practices encountered in the field. There are inherent tensions between Indigenous knowledge and practices, and some Eurocentric approaches that students learn about in university courses. Work by scholars who promote "two-eyed seeing" approaches to education may provide guidance around bringing these traditions and practices together in ways that respect and value both perspectives (Bartlett et al., 2012; Chambers et al., 2018). Critical reflection can be supported through communities of practice (e.g., Cress \& Donahue, 2011), which academic programs and universities can configure in multiple arrangements (Van Leeuwen et al., 2019). Ultimately, students, with adequate and appropriate support from university and field supervisors, should have opportunities to reflect on and think critically about issues of inequality and injustice while developing their knowledge, skills, and attributes as agents of transformative learning and social development.

\section{Limitations and Recommendations for Future Research}

We acknowledge that the research described in this article had limitations. First, all of the study participants were volunteers from the same academic program, and they might have had different motivations than others in discussing their CBL experiences. In addition, this research cannot speak to the CBL experiences of students from other university programs. Choosing hermeneutics to gain a deeper understanding of students' CBL experiences meant giving up some of the thicker descriptions that could 
have been generated through ethnography, with daily observations over a longer period of data collection. Additionally, the researchers' position as outsiders must be acknowledged. While this study focused on student perspectives on CBL in Kenya, the voices of field supervisors, community members, and university faculty were not included. Future research that incorporates their viewpoints and perceptions is recommended. We also suggest that future studies explore the development of a Kenyan CBL model that addresses the potential perpetuation of inequality through Western or Eurocentric CBL practices (Bocci, 2015; Mitchell et al., 2012). This model could highlight unique features and distinctions of CBL in other national contexts. In addition, such a model could encourage greater integration of local epistemologies that would articulate more salient and relevant CBL experiences for Kenyan university students.

\section{Conclusion}

This hermeneutic study revealed the multitude of historical, linguistic, cultural, and social factors comprising the CBL experiences of Kenyan university students. The findings - related to the impact of HIV/AIDS on families and communities, different elements of diversity, and some of the immense social disparities and inequities in Kenya - contribute to an enhanced transnational understanding of civic engagement programs in higher education, with the goal of decolonizing CBL theory and praxis in contexts with unique social, cultural, historical, and linguistic traditions. As an outcome of a crosscultural scholarly collaboration, this article invites broader transnational dialogue around reconceptualizing CBL theory and praxis. Such a reconceptualization is based on an improved understanding of the distinctive sociocultural contexts of CBL in settings such as Kenya, the complex factors influencing students' experiences, and ways to effectively support their learning in these communities. This is not only an ethical stance for greater prosperity, justice, and equity in all societies and communities, but also a necessity if students are to be empowered to become critically reflective and competent citizens and community service professionals.

\section{References}

Adoyo, P. O., \& Odeny, M. L. (2015). Emergent inclusive education practice in Kenya: Challenges and suggestions. International Journal of Research in Humanities and Social Studies, 2(6), 47-52. http://www.ijrhss.org/pdf/v2-i6/7.pdf

Appleton, C. (2011). "Critical friends," feminism and integrity: A reflection on the use of critical friends as a research tool to support researcher integrity and reflexivity in qualitative research studies. Women in Welfare Education, 10, 1-13. http://hdl.handle.net/2292/14443

Ash, S. L., \& Clayton, P. H. (2009). Generating, deepening, and documenting learning: The power of critical reflection for applied learning. Journal of Applied Learning in Higher Education, 1(1), 25-48. http://hdl.handle.net/1805/4579

Avert. (2018). HIV and AIDS in Kenya. https://www.avert.org/professionals/hiv-around-world/subsaharan-africa/kenya

Baglin, M. R., \& Rugg, S. (2010). Student nurses' experiences of community-based practice placement learning: A qualitative exploration. Nurse Education in Practice, 10(3), 144-152. https://doi.org/10.1016/j.nepr.2009.05.008

Banks, J. A. (2016). Multicultural education: Issues and perspectives (6th ed.). John Wiley \& Sons.

Bartlett, C., Marshall, M., \& Marshall, A. (2012). Two-eyed seeing and other lessons learned within a colearning journey of bringing together Indigenous and mainstream knowledges and ways of knowing. Journal of Environmental Studies and Sciences, 2(4), 331-340. https://doi.org/10.1007/s13412-0120086-8

Binding, L. L., \& Tapp, D. M. (2008). Human understanding in dialogue: Gadamer's recovery of the genuine. Nursing Philosophy, 9(2), 121-130. https://doi.org/10.1111/j.1466-769X.2007.00338.x 
Bocci, M. (2015). Service-learning and White normativity: Racial representation in service-learning's historical narrative. Michigan Journal of Community Service Learning, 22(1), 5-17. http://hdl.handle.net/2027/spo.3239521.0022.101

Boler, M., \& Zembylas, M. (2003). Discomforting truths: The emotional terrain of understanding difference. In P. Trifonas (Ed.), Pedagogies of difference: Rethinking education for social change (pp. 110-136). Routledge-Falmer.

Bringle, R. G. (2003). Enhancing theory-based research in service-learning. In S. H. Billig \& J. Eyler (Eds.), Deconstructing service-learning: Research exploring context, participation, and impacts (pp. 25-50). Information Age.

Bringle, R. G., \& Clayton, P. H. (2012). Civic education through service learning: What, how and why? In L. McIlraith, A. Lyons, \& R. Munck (Eds.), Higher education and civic engagement: Comparative perspectives (pp. 101-124). Palgrave Macmillan.

Bringle, R. G., \& Hatcher, J. A. (1996). Implementing service learning in higher education. Journal of Higher Education, 67(2), 221-239. https://doi.org/10.1080/00221546.1996.11780257

Brownell, J. E., \& Swaner, L. E. (2010). Five high-impact practices: Research on learning outcomes, completion, and quality. Association of American Colleges and Universities.

Carson, T. R. (1986). Closing the gap between research and practice: Conversation as a mode of doing research. Phenomenology + Pedagogy, 4(2), 73-85. https://doi.org/10.29173/pandp15019

Chambers, L. A., Jackson, R., Worthington, C., Wilson, C. L., Tharao, W., Greenspan, N. R., Masching, R., Pierre-Pierre, V., Mbulaheni, T., Amirault, M., \& Brownlee, P. (2018). Decolonizing scoping review methodologies for literature with, for, and by Indigenous peoples and the African diaspora: Dialoguing with the tensions. Qualitative Health Research, 28(2), 175-188. http://doi.org/10.1177/1049732317743237

Chambers, T. (2009). A continuum of approaches to service-learning within Canadian post-secondary education. Canadian Journal of Higher Education, 39(2), 77-100. https://journals.sfu.ca/cjhe/index.php/cjhe/article/view/486/515

Clarke, M., \& Drudy, S. (2006). Teaching for diversity, social justice and global awareness. European Journal of Teacher Education, 29(3), 371-386. https://doi.org/10.1080/02619760600795239

Clayton, P. H., Bringle, R. G., \& Hatcher, J. A. (Eds.). (2013a). Research on service learning: Conceptual frameworks and assessment: Vol. 2A. Students and faculty. Stylus.

Clayton, P. H., Bringle, R. G., \& Hatcher, J. A. (Eds.). (2013b). Research on service learning: Conceptual frameworks and assessment: Vol. 2B. Communities, institutions, and partnerships. Stylus.

Cloete, N., Bailey, T., Pillay, P., Bunting, I., \& Maassen, P. (2011). Universities and economic development in Africa: Pact, academic core and coordination. Centre for Higher Education Transformation.

Costa, A. L., \& Kallick, B. (1993). Through the lens of a critical friend. Educational Leadership, 51(2), 49-51. http://www.ascd.org/publications/educational-leadership/oct93/vol51/num02/Through-theLens-of-a-Critical-Friend.aspx

Crabtree, R. D. (2008). Theoretical foundations for international service-learning. Michigan Journal of Community Service Learning, 15(1), 18-36. http://hdl.handle.net/2027/spo.3239521.0015.102

Cress, C. M. (2018, December 14). The role of emotional entropy in dismantling ethnocentric paradigms: American student encounters with power, privilege, and global agency through service-learning in India. Public presentation at the University of Prince Edward Island.

Cress, C. M., \& Donahue, D. M., \& Associates (2011). Democratic dilemmas of teaching servicelearning: Curricular strategies for success. Stylus.

Davey, N. (2006). Unquiet understanding: Gadamer's philosophical hermeneutics. SUNY Press.

Dei, G. J. S. (2000). African development: The relevance and implications of indigenousness. In G. J. S. Dei, B. L. Hall, \& D. G. Rosenberg (Eds.), Indigenous knowledges in global contexts: Multiple readings of our world (pp. 70-86). University of Toronto Press. 
Eyler, J. (2002). Stretching to meet the challenge: Improving the quality of research to improve the quality of service-learning. In S. H. Billig \& A. Furco (Eds.), Service-learning through a multidisciplinary lens (pp. 3-14). Information Age.

Eyler, J. (2009). The power of experiential education. Liberal Education, 95(4), 24-31. https://files.eric.ed.gov/fulltext/EJ871318.pdf

Finley, A. (Ed.). (2014). Civic learning and teaching: A bridge to civic life and a life of learning. Bringing Theory to Practice. https://www.bttop.org/sites/default/files/public/CivicTaL\%20FINAL.pdf

Fitzgerald, H. E. (2007). Creating a new kind of university: Institutionalising community-university engagement. The Review of Higher Education, 30(2), 203-205. http://doi.org/10.1353/rhe.2006.0068

Fourie, C. M. (2003). Deep learning? What deep learning? South African Journal of Higher Education, 17(1), 123-131. https://doi.org/10.4314/sajhe.v17i1.25201

Gadamer, H. G. (1975). Truth and method. Seabury Press. (Original work published 1960)

Giles, D. E., Jr., \& Eyler, J. (1994a). The impact of a college community service laboratory on students' personal, social, and cognitive outcomes. Journal of Adolescence, 17, 327-339. https://digitalcommons.unomaha.edu/slcehighered/187

Giles, D. E., Jr., \& Eyler, J. (1994b). The theoretical roots of service-learning in John Dewey: Toward a theory of service-learning. Michigan Journal of Community Service Learning, 1(1), 77-85. http://hdl.handle.net/2027/spo.3239521.0001.109

Giles, D. E., Jr., \& Eyler, J. (2013). The endless quest for scholarly respectability in service-learning research. Michigan Journal of Community Service Learning, 20(1), 53-64. http://hdl.handle.net/2027/spo.3239521.0020.105

Greiner, C., \& Sakdapolrak. P. (2013). Rural-urban migration, agrarian change, and the environment in Kenya: A critical review of the literature. Population and Environment, 34(4), 524-553. https://doi.org/10.1007/s11111-012-0178-0

Gudo, C. O., Olel, M. A., \& Oanda, I. O. (2011). University expansion in Kenya and issues of quality education: Challenges and opportunity. International Journal of Business and Social Science, 2(20), 203-214. http://www.ijbssnet.com/journals/Vol_2_No_20_November_2011/22.pdf

Guo, L. (2010). The meaning of curriculum reform for Chinese teachers: $\bar{A}$ hermeneutic inquiry into teachers' lived experiences in curriculum change. Lambert Academic Publishing.

Hartman, E., Kiely, R. C., Boettcher, C., \& Friedrichs, J. (2018). Community-based global learning: The theory and practice of ethical engagement at home and abroad. Stylus.

Hatcher, J. A., \& Erasmus, M. A. (2008). Service-learning in the United States and South Africa: A comparative analysis informed by John Dewey and Julius Nyerere. Michigan Journal of Community Service Learning, 15(1), 49-61. http://hdl.handle.net/2027/spo.3239521.0015.104

Holsapple, M. A. (2012). Service-learning and student diversity outcomes: Existing evidence and directions for future research. Michigan Journal of Community Service Learning, 18(2), 5-18. http://hdl.handle.net/2027/spo.3239521.0018.201

Hovey, R. B., Delormier, T., McComber, A. M., Lévesque, L., \& Martin, D. (2017). Enhancing indigenous health promotion research through two-eyed seeing: A hermeneutic relational process. Qualitative Health Research, 27(9), 1278-1287. https://doi.org/10.1177/1049732317697948

ICEF Monitor. (2015, June 1). Governments and educators in Kenya struggling to keep pace with demand for higher education. http://monitor.icef.com/2015/06 /governments-and-educators-in-kenya-struggling-to-keep-pace-with-demand-for-higher-education/

Jacobs, A. H. M. (2014). Critical hermeneutics and higher education: A perspective on texts, meaning and institutional culture. South African Journal of Philosophy, 33(3), 297-310. https://doi.org/10.1080/02580136.2014.948327

Jacoby, B. (2014). Service-learning essentials: Questions, answers, and lessons learned. Jossey-Bass.

Kabaria-Muriithi, J., VanLeeuwen, C. A., Kathuri-Ogola, L., \& Weeks, L. E. (2018). Expectations of field supervisors in Kenya: Implications for community-based human service practicums. Gateways: International Journal of Community Research, 11(1), 1-17. https://doi.org/10.5130/ijcre.v11i1.5439 
Karanja, L. (2010). "Homeless" at home: Linguistic, cultural, and identity hybridity and third space positioning of Kenyan urban youth. Comparative and International Education/Éducation Comparée et Internationale, 39(2), Article 2. https://ir.lib.uwo.ca/cie-eci/vol39/iss2/2

Kathuri-Ogola, L., VanLeeuwen, C., Kabaria-Muriithi, J., Weeks , L. E., Kieru, J., \& Ndayala, P. (2015). Supervision challenges encountered during Kenyan university students' practicum attachment. Journal of Education and Practice, 6(17), 111- 117. http://iiste.org/Journals/index.php/JEP/article/view/23596

Kenya National AIDS Control Council. (2014). Kenya AIDS Strategic Framework 2014/20152018/2019. http://nacc.or.ke/wp-content/uploads/2015/09/KASF Final.pdf

Kohler, P. K., Ondenge, K., Mills, L. A., Okanda, J., Kinuthia, J., Olilo, G., Odhiambo, F., Laserson, K. F., Zierler, B., Voss, J., \& John-Stewart, G. (2014). Shame, guilt, and stress: Community perceptions of barriers to engaging in prevention of mother to child transmission (PMTCT) programs in Western Kenya. AIDS Patient Care and STDs, 28(12), 643-651. https://doi.org/10.1089/apc.2014.0171

Lee, L., \& Chen, P. (2014). Empowering indigenous youth: Perspectives from a national service-learning program in Taiwan. International Indigenous Policy Journal, 5(3), Article 4. https://doi.org/10.18584/iipj.2014.5.3.4

Le Grange, L. (2007). The "theoretical foundations" of community service-learning: From taproots to rhizomes. Education as Change, 11(3), 3-13. https://doi.org/10.1080/16823200709487174

McCaffrey, G., Raffin-Bouchal, S., \& Moules, N. J. (2012). Hermeneutics as research approach: A reappraisal. International Journal of Qualitative Methods, 11(3), 214-229. https://doi.org/10.1177\%2F160940691201100303

McMillan, J. (2018). What happens when the university meets the community? Service learning, boundary work and boundary workers. Teaching in Higher Education, 16(5), 553-564. https://doi.org/10.1080/13562517.2011.580839

McMillan, J., \& Stanton, T. K. (2014). "Learning service" in international contexts: Partnership-based service-learning and research in Cape Town, South Africa. Michigan Journal of Community Service Learning, 21(1), 64-78. http://hdl.handle.net/2027/spo.3239521.0021.106

Meda, S. G. (2013). Single mothers of Nairobi: Rural-urban migration and the transformation of gender roles and family relations in Kenya. Urban People, 15(2), 279-307. https://pdfs.semanticscholar.org/7638/eca4524fd6580215f430507a78721f869d8d.pdf?.ga=2.4931056 6.1541311529.1588626469-837654901.1588626469

Mitchell, T. D. (2008). Traditional vs. critical service-learning: Engaging the literature to differentiate two models. Michigan Journal of Community Service Learning, 14(2), 50-65. http://hdl.handle.net/2027/spo.3239521.0014.205

Mitchell, T. D., Donahue, D. M., \& Young-Law, C. (2012). Service learning as a pedagogy of Whiteness. Equity \& Excellence in Education, 45(4), 612-629. https://doi.org/10.1080/10665684.2012.715534

Moules, N. J. (2002). Hermeneutic inquiry: Paying heed to history and Hermes. An ancestral, substantive, and methodological tale. International Journal of Qualitative Methods, 1(3), 1-21. https://doi.org/10.1177/160940690200100301

Moules, N. J., McCaffrey, G., Field, J. C., \& Laing, C. M. (2015). Conducting hermeneutic research: From philosophy to practice. Peter Lang. https://doi.org/10.3726/978-1-4539-1473-1

Muaka, L. (2011). Language perceptions and identity among Kenyan speakers. In E. G. Bokamba et al. (Eds.), Proceedings of the 40th Annual Conference on African Linguistics (pp. 217-230). Cascadilla Proceedings Project. http://www.lingref.com/cpp/acal/40/paper2577.pdf

Mudavanhu, D. (2008). The psychosocial impact on rural grandmothers caring for their grandchildren orphaned by HIV/AIDS [Doctoral dissertation, University of South Africa]. UNISA Institutional Repository.

Mudavanhu, D., Segalo, P., \& Fourie, E. (2008). Grandmothers caring for their grandchildren orphaned by HIV and AIDS. New Voices in Psychology, 4(1), 76-97. https://hdl.handle.net/10520/EJC112559 
Mukuria, V. (2008). Civic engagement in Kenya: Developing students' leadership through service learning [Doctoral dissertation, Ohio State University]. https://etd.ohiolink.edu/!etd.send_file?accession=osu1218647818

Nyangau, J. Z. (2014). Higher education as an instrument for economic growth in Kenya. FIRE: Forum for International Research in Education, 1(1), Article 3. https://doi.org/10.18275/fire201401011006

Oanda, I. O., \& Jowi, J. (2012). University expansion and the challenges to social development in Kenya: Dilemmas and pitfalls. Journal of Higher Education in Africa, 10(1), 49-71. https://www.jstor.org/stable/jhigheducafri.10.1.49

O'Brien, F. (2005). Grounding service learning in South Africa. Acta Academica Supplementum, 3, 64 98. https://pdfs.semanticscholar.org/b7e9/e910b37be80c0bfbd3b5ff147238d6dd0bfc.pdf

Odongo, R. A. (2018). Students' perception of a required community service program in Kenya [Doctoral dissertation, Walden University]. Walden Dissertations and Doctoral Studies Collection. https://scholarworks.waldenu.edu/cgi/viewcontent.cgi?article $=5945 \&$ context $=$ dissertations

Ondigi, S. R. (2011). Globalisation of university programmes and community linkages: A case of two Kenyan Universities. International Journal of Humanities and Social Science, 1(3), 96-105. http://irlibrary.ku.ac.ke/handle/123456789/9811

Opiyo-Newa, E. (2012). Assessing the internship program in universities: Case study of United States International University. Journal of Language, Technology and Entrepreneurship in Africa, 3(2), 112-119. https://www.ajol.info/index.php/jolte/article/view/76975

Paterson, M., \& Higgs, J. (2005). Using hermeneutics as a qualitative research approach in professional practice. Qualitative Report, 10(2), 339-357. https://nsuworks.nova.edu/tqr/vol10/iss2/9

Patton, M. Q. (2015). Qualitative research and evaluation methods (4th ed.). Sage.

Pollack, S. (2014). (Social) justice for all (undergraduate degree programs): Institutionalizing critical civic literacy in the undergraduate curriculum. In A. Finley (Ed.), Civic learning and teaching: A bridge to civic life and a life of learning (pp. 9-18). Bringing Theory to Practice. https://usm.maine.edu/sites/default/files/center-collaboration-development/MMU_CivicTeaching AndLearning-BTP-AACU.pdf

Preece, J. (2016). Negotiating service learning through community engagement: Adaptive leadership, knowledge, dialogue and power. Education as Change, 20(1), 104-125. https://doi.org/10.17159/1947-9417/2016/562

Roos, V., Temane, Q. M., Davis, L., Prinsloo, C. E., Kritzinger, A., Naudé, E., \& Wessels, J. C. (2005). Service learning in a community context: Learners' perceptions of a challenging training paradigm. South African Journal of Psychology, 35(4), 703-716. https://doi.org/10.1177\%2F008124630503500406

Sandelowski, M. (1995). Sample size in qualitative research. Research in Nursing \& Health, 18(2), 179183. https://doi.org/10.1002/nur.4770180211

Sharpe, E. K., \& Dear, S. (2013). Points of discomfort: Reflections on power and partnerships in international service-learning. Michigan Journal of Community Service Learning, 19(2), 49-57. http://hdl.handle.net/2027/spo.3239521.0019.204

Simons, L., Fehr, L., Blank, N., Connell, H., Georganas, D., Fernandez, D., \& Peterson, V. (2012). Lessons learned from experiential learning: What do students learn from a practicum/ internship? International Journal of Teaching and Learning in Higher Education, 24(3), 325-334. http://www.isetl.org/ijtlhe/pdf/IJTLHE1315.pdf

Solomon, R. P., \& Singer, J. (2011). Distinguishing our present context: The meaning of diversity and education for social justice. In R. P. Solomon, J. Singer, A. Campbell, A. Allen, \& J. P. Portelli (Eds.), Brave new teachers: Doing social justice work in neo-liberal times (pp. 1-30). Canadian Scholars' Press.

Stanton, T. K., \& Erasmus, M. A. (2013). Inside out, outside in: A comparative analysis of servicelearning's development in the United States and South Africa. Journal of Higher Education Outreach and Engagement, 17(1), 63-96. https://files.eric.ed.gov/fulltext/EJ1005300.pdf 
Swaner, L. E. (2012). The theories, contexts and multiple pedagogies of engaged learning: What succeeds and why? In D. W. Harward (Ed.), Transforming undergraduate education: Theory that compels and practices that succeed (pp. 73-89). Rowman \& Littlefield.

Thomson, A. M., Smith-Tolken, A. R., Naidoo, A. V., \& Bringle, R. G. (2011). Service learning and community engagement: A comparison of three national contexts. Voluntas, 22, 214-237. http://doi.org/10.1007/s11266-010-9133-9

Tonkin, H. (2011). A research agenda for international service learning. In R. G. Bringle, J. A. Hatcher, \& S. G. Jones (Eds.), International service learning (pp. 191-224). Stylus.

Tumuti, D. W., Mule, L. W., Gecaga, M., \& Manguriu, D. G. (2013). Enhancing graduate employability through community engagement: A case study of students' community service at Kenyatta University. Journal of Administrative Sciences and Policy Studies, 1(1), 1-14. http://irlibrary.ku.ac.ke/handle/123456789/13163

UNAIDS. (2017). Country: Kenya. http://www.unaids.org/en/regionscountries/countries/kenya

United Nations. (2015). Sustainable development goals. https://sustainabledevelopment.un.org/sdgs

VanLeeuwen, C. A., Guo-Brennan, L., \& Weeks, L. E. (2017). Conducting hermeneutic research in international settings: Philosophical, practical and ethical considerations. Journal of Applied Hermeneutics, Article 7. https://doi.org/10.11575/jah.v0i0.53309

VanLeeuwen, C. A., Kathuri-Ogola, L., Weeks, L. E., \& Kabaria Muriithi, J. (2018). An evidence-based professional practice course for practicum students at a Kenyan university. Family and Consumer Sciences Research Journal, 43(3), 238-251. https://doi.org/10.1111/fcsr.12248

VanLeeuwen, C. A., Weeks, L. E., \& Guo-Brennan, L. (2017). Indigenous perspectives in community service-learning in higher education: An examination of the Kenyan context. International Journal of Research on Service-Learning and Community Engagement, 5(1), 129-143. https://journals.sfu.ca/iarslce/index.php/journal/article/view/252

VanLeeuwen, C. A., Weeks, L. E., \& Guo-Brennan, L. (2019). Critical pedagogy of discomfort in community-based learning: Kenyan students' experiences. Comparative and International Education/Éducation Comparée et International, 48(1), Article 4. https://ir.lib.uwo.ca/cieeci/vol48/iss $1 / 4 /$

van Wyk, J-A., \& Daniels, F. (2004). An integrated mentoring strategy for service learning in higher education. South African Journal of Higher Education, 18(2), 359-370. https://doi.org/10.4314/sajhe.v18i2.25475

Weisbrod, B. A., Ballou, J. P., \& Asch, E. D. (2011). Mission and money: Understanding the university. Cambridge University Press. https://doi.org/10.1017/CBO9780511511011

Wiesmann, U., Kiteme, B., \& Mwangi, Z. (2016). Socio-economic atlas of Kenya: Depicting the national population census by county and sub-location (2nd ed.). National Bureau of Statistics. https://doi.org/10.7892/boris.83693

Whitley, M. A. (2014). A draft conceptual framework of relevant theories to inform future rigorous research on student service-learning outcomes. Michigan Journal of Community Service Learning, 20(2), 19-40. http://hdl.handle.net/2027/spo.3239521.0020.202

Xing, J., \& Ma, C. H. K. (Eds.) (2010). Service-learning in Asia: Curricular models and practices. Hong Kong University Press. https://doi.org/10.5790/hongkong/9789888028467.001.0001

Zembylas, M. (2015). "Pedagogy of discomfort" and its ethical implications: The tensions of ethical violence in social justice education. Ethics and Education, 10(2), 163-174. https://doi.org/10.1080/17449642.2015.1039274

\section{About the Authors}

Charlene A. VanLeeuwen is a sessional lecturer in the Department of Applied Human Sciences at the University of Prince Edward Island, Canada. 
Linyuan Guo-Brennan is an associate professor in the Faculty of Education at the University of Prince Edward Island, Canada.

Lori E. Weeks is an associate professor in the School of Nursing at Dalhousie University, Canada.

Correspondence concerning this article should be addressed to Charlene A. VanLeeuwen at cvanleeuwen@upei.ca. 